\title{
EFEKTIVITAS MEDIASI SEBAGAI UPAYA PENYELESAIAN PERSELISIHAN PEMUTUSAN HUBUNGAN KERJA (STUDI PADA CV. ANUGRAH JAYA KAB. BANGKALAN)
}

\author{
Ana Sokhifatul Mufida, Meike Rizki Damayanti, Reda Prastyo \\ Universitas Trunojoyo Madura
}

\begin{abstract}
This article discusses about the effectiveness of mediation as conflict completion effort of the termination of employment.This article aims to know the effectiveness of mediation as conflict completion effort of the termination at CV. Anugrah Jaya Bangkalan. This type of research uses analytical descriptive, in order to describe and analyze disputes that occur at CV. Anugrah Jaya Indicators of the dispute are one of the workers named Ika Oktaviani who has embezzled the company's money. From the results of the study can be concluded, mediation as an effort to resolve disputes on termination of employment at CV. Anugrah Jaya works effectively. Mediation is carried out at the Department Of Industry and Labor Bangkalan, where the role of the mediator is very much needed until finally there is a decision that Ika Oktaviani was laid off by $\mathrm{CV}$. Anugrah Jaya.
\end{abstract}

Key words: Effectieness, Mediation, Termination of Employment

\section{PENDAHULUAN}

Industri merupakan sarana penting dalam peningkatan perekonomian di Indonesia. Di dalam industri terdapat dua faktor penggerak yang saling berhubungan antara yang satu dengan yang lain, yaitu pekerja dengan pengusaha. Pekerja adalah tenaga kerja yang bekerja didalam hubungan kerja pada pengusaha dengan menerima upah (Budiono, 2011:8). Pekerja dalam melakukan suatu pekerjaan harus ada suatu hubungan yang saling menguntungkan baik pada pihak pekerja maupun dipihak pengusaha. Sedangkan berdasarkan Undang-undang No. 2 tahun 2004 pasal 1 angka 6 Pengusaha adalah:

1. Orang perseorangan, persekutuan, atau badan hukum yang menjalankan suatu perusahaan milik sendiri

2. Orang perseorangan, persekutuan, atau badan hukum yang secara berdiri sendiri menjalankan perusahaan bukan miliknya

3. Orang perseorangan, persekutuan, atau badan hukum yang berada di Indonesia mewakili perusahaan sebagaimana dimaksud dalam huruf a dan $b$ yang berkedudukan di luar wilayah Indonesia. 
Suatu hubungan kerja akan terjalin ketika ada pekerja dan pengusaha yang samasama berhubungan antara satu dengan yang lain dalam menghasilkan suatu barang atau jasa. Dalam hal ini kedudukan baik pekerja maupun pengusaha adalah saling membutuhkan antara satu dengan yang lain. Pekerja membutuhkan pengusaha agar dapat bekerja dan mendapatkan penghasilan untuk mencukupi kebutuhan hidupnya, sedangkan pengusaha membutuhkan pekerja untuk menghasilkan barang atau jasa sehingga usahanya dapat terus berjalan.

Hubungan inilah yang semestinya dapat terjalin dengan baik sehingga dapat tercipta suatu iklim yang baik antara pekerja dengan pengusaha. Apabila hubungan kerja tersebut dapat berjalan dengan baik, kedua belah pihak dapat melakukan tugas serta tanggung jawabnya dengan baik. Maka akan tercipta iklim kerja yang harmonis antar kedua belah pihak. Hubungan yang harmonis antara pekerja dengan pegusaha sangat dibutuhkan, karena apabila terjadi ketegangan antara kedua belah pihak maka dampaknya akan sangat besar baik bagi pihak pekerja maupun pihak pengusaha.

Dalam suatu hubungan kerja antara pengusaha dan pekerja didasarkan pada suatu perjanjian kerja yang memiliki unsur pekerjaan, upah, dan perintah. Namun, tidak selamanya hubungan antara pengusaha dan pekerja berjalan dengan baik, dimana kadangkala pengusaha dan pekerja tidak selalu memiliki persamaan pendapat, sehingga perbedaan pendapat antara pengusaha dan pekerja dapat menyebabkan adanya perselisihan hubungan industrial. Perselisihan yang terjadi akibat adanya perbedaan yang mengakibatkan pertentangan, karena pada dasarnya manusia merupakan makhluk sosial yang dalam berinteraksi memiliki persamaan dan perbedaan dalam kepentingan maupun cara pandang, sehingga sangat dimungkinkan terjadinya perselisihan yang berujung pada pemutusan hubungan kerja.

Pemutusan Hubungan Kerja berdasarkan ketentuan pasal 1 angka 25 Undangundang Nomor 13 Tahun 2003 adalah pengakhiran hubungan kerja karena suatu hal tertentu mengakibatkan berakhirnya hak dan kewajiban antara pekerja dan pengusaha. Menurut Asri (2010:158) PHK merupakan suatu keadaan di mana si buruh berhenti bekerja dari majikannya. PHK bagi pekerja merupakan permulaan dari berakhirnya mempunyai pekerjaan, permulaan dari berakhirnya kemampuannya membiayai keperluan hidup sehari-hari baginya dan keluarganya. Sehingga pemutusan hubungan kerja merupakan peristiwa yang tidak diharapkan. Khusunya bagi pekerja, kerena pemutusan 
hubungan kerja akan memberikan dampak psycologis-financiil bagi pekerja dan keluarganya. PHK harus dijadikan tindakan terakhir apabila ada perselisihan hubungan industrial. Pengusaha dalam menghadapi para pekerja hendaknya menjalin hubungan baik dengan para pekerjanya.

Penyelesaian kasus Perselisihan Hubungan Industria dan PHK memerlukan tata cara menurut perundang-undangan yang berlaku agar dapat menciptakan suasana kemantapan, ketertiban, sehingga terwujudlah penyelesaian yang efektif, efesien, murah, dan adil dengan dilandasi musyawarah mufakat antara pihak yang berselisih. Dengan demikian, permasalahan ketenagakerjaan dapat diselesaikan dengan baik.

Penyelesaian perselisihan hubungan industrial berdasarkan Undang-undang Nomor 2 Tahun 2004 tentang Penyelesaian Perselisihan Hubungan Industrial terdapat dua cara penyelesaian, yaitu penyelesaian perselisihan melalui pengadilan hubungan industrial (litigasi) dan diluar pengadilan hubungan industrial (non litigasi) yang meliputi penyelesaian secara Bipartid, Mediasi, Konsiliasi, atau Arbitase. Setiap perselisihan hubungan industrial, termasuk perselisihan PHK wajib diupayakan penyelesaiannya terlebih dahulu melalui perundingan bipartid. Perundingan bipartid dilakukan dengan cara musyawarah antara pekerja dan pengusaha. Apabila dalam perundingan bipartid tidak terjadi kesepakatan maka, salah satu pihak atau kedua belah pihak mencatatkan perselisihannya kepada instansi yang bertanggung jawab di bidang ketenagakerjaan. Selanjutnya Dinas Perindustrian dan Tenaga Kerja akan menawarkan kepada para pihak akan menyelesaikan melalui konsiliasi ataukah melalui mediasi untuk perselisihan PHK.

Mediasi adalah salah satu cara untuk menyelesaikan perselisihan hubungan industrial. Menurut Pasal 1 angka 11 UU No. 2 Tahun 2004 Tentang Penyelesaian Perselisihan Hubungan Industrial, Mediasi Hubungan Industrial yang selanjutnya disebut mediasi adalah

1. Penyelesaian perselisihan hak adalah perselisihan yang timbul karena tidak dipenuhinya hak, akibat adanya perbedaan pelaksanaan atau penafsiran terhadap ketentuan perundang-undangan, perjanjian kerja, peraturan perusahaan atau perjanjian kerja bersama

2. Perselisihan kepentingan adalah perselisihan dalam hubungan kerja yang timbul karena adanya keserasian pendapat mengenai pembuatan maupun perubahan 
syarat-syarat kerja yang ditetapkan dalam Perjanjian kerja, peraturan perusahaan atau perjanjian kerja bersama

3. Perselisihan pemutusan hubungan kerja adalah perselisihan yang timbul karena tidak adanya kesesuaian pendapat mengenai pengakhiran kerja yang dilakukan oleh salah satu pihak

4. Perselisihan antar serikat pekerja/serikat buruh adalah perselisihan antara serikat pekerja atau serikat buruh yang satu dengan serikat pekerja atau serikat buruh yang lain dalam satu perusahaan, karena tidak adanya persesuaian paham mengenai keanggotaan, pelaksanaan hak dan kewajiban serikat pekerja

Perselisihan yang terjadi hanya dalam satu perusahaan melalui musyawarah yang ditengahi oleh seorang atau lebih mediator yang netral. Tujuan diselesaikannya Perselisihan Hubungan Industrial melalui mediasi adalah agar tercapai kesepakatan dan perdamaian antara kedua belah pihak.

Penyelesaian perselisihan PHK melalui mediasi dilakukan oleh mediator yang berada di setiap kantor instansi yang bertanggung jawab di bidang ketenagakerjaan kabupaten atau kota. Mediator yang berperan dalam penyelesaian perselisihan hubungan industrial adalah pegawai instansi pemerintah yang bertanggung jawab di bidang ketenagakerjaan yang memenuhi syarat-syarat sebagai mediator yang ditetapkan oleh Menteri untuk bertugas melakukan mediasi dan mempunyai kewajiban memberikan anjuran tertulis kepada para pihak yang berselisih untuk menyelesaikan perselisihan hak, perselisihan kepentingan, perselisihan pemutusan hubungan kerja, dan perselisihan antar serikat pekerja/seikat buruh hanya dalam satu perusahaan.

Berdasarkan data yang diperoleh dari Dinas Perindustrian dan Tenaga Kerja Bangkalan pada tahun 2018 terdapat beberapa kasus perselisihan hubungan industrial, yang hampir kebanyakan merupakan kasus perselisihan PHK. Seluruh perselisihan PHK yang masuk ke Dinas Perindustrian dan Tenaga Kerja Bangkalan diselesaikan melalui Mediasi. Undang-undang Nomor 13 Tahun 2003 tentang Ketenagakerjaan menegaskan bahwa apabila terjadi suatu pemutusan hubungan kerja, maka pengusaha diwajibkan untuk membayar hak-hak yang seharusnya diterima oleh pekerja, yang diantaranya berupa:

1. Uang pesangon merupakan pembayaran berupa uang dari pengusaha kepada pekerja sebagai akibat adanya Pemutusan Hubungan Kerja (PHK). 
2. Uang penghargaan masa kerja merupakan uang jasa sebagai penghargaan pengusaha kepada pekerja yang dikaitkan dengan lamanya masa kerja.

3. Ganti kerugian merupakan pembayaran berupa uang dari pengusaha kepada pekerja sebagai pengganti istirahat tahunan, istirahat panjang, biaya perjalanan, fasilitas perumahan, dan lain-lain.

Dari beberapa kasus yang melaporkan ke Dinas Perindustrian dan Tenaga Kerja, salah satu kasus yang terjadi di bangkalan adalah kasus perselisihan antara pekerja yang bernama Ika Oktaviani dengan CV. Anugrah Jaya. Permasalahannya adalah Ika Oktaviani telah menggelapakan uang perusahaan. Namun Ika Oktaviani tidak mengakui perbuatan tersebut. Sehingga pihak CV. Anugrah Jaya melaporkan kasus ini ke jalur tripatid yaitu mediasi, guna menyelesaikan perselisihan tanpa harus membawa ke pengadilan.Dengan melihat permasalahan tersebut, maka penulis dalam artikel ini akan membahas mengenai efektivitas mediasi sebagai upaya penyelesaian perselisihan pemutusan hubungan kerja pada CV. Anugrah Jaya.

\section{Permasalahan}

Bagaimana efektivitas mediasi sebagai upaya penyelesaian perselisihan pemutusan hubungan kerja pada CV. Anugrah Jaya Kab. Bangkalan?

\section{TINJAUAN PUSTAKA}

\section{Pengertian Efektivitas}

Dalam setiap proses kegiatan untuk mencapai tujuan, pasti mempunyai prinsip. Keberhasilan suatu sistem kerja guna mencapai tujuan seiring diukur dari tingkat efektivitas dan efisiensi dalam menggunakan sumber daya yang dimiliki, karena efektivitas kerja menjadi tuntutan setiap pencapaian tujuan. Penulis disini akan mengutipkan pendapat-pendapat mengenai efektivitas kerja:

Menurut Kurniawan (2005:109) "efektivitas adalah kemampuan melaksanakan tugas, fungsi (operasi kegiatan program atau misi) daripada suatu organisasi atau sejenisnya yang tidak adanya tekanan atau ketegangan diantara pelaksananya". Menurut Siagian (2007:24) mengemukakan bahwa, efektivitas kerja adalah penyelesaian pekerjaan tepat pada waktunya yang telah ditetapkan, artinya apakah pelaksanaan kerja suatu tugas dinilai baik atau tidak itu tergantung pada bilamana tugas itu diselesaikan, dan tidak 
terutama menjawab bagaimana cara menyelesaikan, melaksanakan, dan berapa biaya yang harus dikeluarkan untuk itu.

Menurut Ravianto dalam Masruri (2014:11) efektivitas adalah seberapa baik pekerjaan yang dilakukan, sejauh mana orang menghasilkan keluaran sesuai dengan yang diharapkan. Ini berarti bahwa apabila suatu pekerjaan dapat diselesaikan dengan perencanaan, baik dalam waktu, biaya maupun mutunya, maka dapat dikatakan efektif Menurut Bungkaes (2013:45) efektivitas adalah hubungan antara output dan tujuan. Dalam artian efektivitas merupakan ukuran seberapa jauh tingkat output, kebijakan dan prosedur dari organisasi mencapai tujuan yang ditetapkan. Dalam pengertian teoritis atau praktis, tidak ada persetujuan yang universal mengenai apa yang dimaksud dengan "Efektivitas". Bagaimanapun definisi efektivitas berkaitan dengan pendekatan umum. Bila ditelusuri efektivitas berasal dari kata dasar efektif yang artinya:

1. Ada efeknya (pengaruh, akibatnya, kesannya) seperti: manjur, mujarab, mempan

2. Penggunaan metode/cara, saran/alat dalam melaksanakan aktivitas sehungga berhasil guna (mencapai hasil yang optimal)

Menurut Gibson et.al dalam Bungkaes (2013:46) efektivitas adalah penilaian yang dibuat sehubungan dengan prestasi individu, kelompok, dan organisasi. Makin dekat prestasi mereka terhadap prestasi yang diharapkan (standar), maka makin lebih efektif dalam menilai mereka.

\section{Pengertian Mediasi}

Pengertian mediasi dalam hubungan industrial adalah penyelesaian perselisihan hak, perselisihan kepentingan, perselisihan pemutusan hubungan industrial, dan penyelesaian perselisihan antar serikat buruh hanya dalam satu perusahaan melalui musyawarah yang ditengahi oleh seorang atau lebih mediator yang netral (Abdul $\mathrm{R}$ Budiono 2011:226), dalam pengertian tersebut juga sama seperti yang terdapat di dalam Undang-undang No.2 tahun 2004.

Menurut Saifullah (2009), mediasi adalah sebuah kata yang berasal dari bahasa inggris "mediation" yang memiliki arti penyelesaian sengketa dengan cara menengahi sehingga dapat memberikan kesimpulan (win-win solution) sama-sama menguntungkan para pihak. Menurut Takdir Rahmadi (2011:12), mediasi adalah suatu proses penyelesaian 
sengketa antara dua pihak atau lebih melalui perundingan atau cara mufakat dengan bantuan pihak netral yang tidak memiliki kewenangan memutus.

Dalam permasalahan perselisihan hubungan industrial, mediasi merupakan suatu terobosan yang bisa digunakan untuk menyelesaikan perselisihan hubungan industrial. Hal ini jika dibandingkan dengan penyelesaian perselisihan dengan menggunakan jalur pengadilan. Selain itu mediasi lebih karena dalam mediasi dilakukan untuk mendapatkan win-win solution. Yaitu menang sama menang untuk mencari penyelesaian jalan tengah atas perselisihan yang terjadi antara kedua belah pihak.

\section{Pengertian Mediator}

Menurut Saifullah (2009), mediator adalah seseorang atau tim ahli yang membantu dalam menangani masalah melalui proses perundingan yang dihadiri para pihak. Menurut Syahrizal (20011:58) mediator adalah pihak ketiga yang membantu penyelesaian sengketa para pihak, yang mana ia tidak melakukan intervensi terhadap pengambilan keputusan.

Dalam pasal 1 ayat 6 PERMA no 1 tahun 2008 menyatakan bahwa mediator adalah pihak netral yang membantu para pihak yang bersengketa dalam proses perundingan guna mencari berbagai kemungkinan penyelesaian sengketa tanpa menggunakan cara memutus atau memaksakan sebuah penyelesaian.

Beberapa persyaratan mediator adalah sebagai berikut:

1. Kemampuan membangun kepercayaan para pihak

2. Kemampuan menunjukkan sikap empati

3. Tidak menghakimi dan memberikan reaksi positif terhadap sejumlah pernyataan yang disampaikan para pihak dalam proses mediasi, walaupun ia sendiri tidak setuju dengan pernyataan tersebut.

4. Kemampuan komunikasi yang baik, jelas dan teratur, serta mudah dipahami para pihak karena menggunakan bahasa yang sederhana.

5. Keberadaan mediator disetujui oleh kedua belah pihak

6. Tidak memiliki hubungan sedarah dengan salah satu pihak yang bersengketa

7. Tidak memiliki hubungan kerja dengan salah satu pihak yang bersengketa

8. Tidak memiliki kepentingan terhadap proses perundingan maupun hasilnya (Syahrizal, 2011:59-60) 


\section{Pemutusan Hubungan Kerja}

PHK adalah suatu langkah pengahiran hubungan kerja antara buruh dan majikan karena suatu hal tertentu (Halim, A. Ridwan, 1990: 136). PHK adalah langkah pengakhiran hubungan kerja antara buruh atau pekerja dengan majikan atau pengusaha yang disebabkan karena suatu keadaan tertentu (Zaeni Asyhadie, 2002: 139). Menurut KEP-15A/MEN/1994 Pasal 1 ayat (4) PHK adalah "pengakhiran hubungan kerja antara pengusaha dan pekerja berdasarkan izin Panitia Daerah/ Panitia Pusat”.

Menurut Undang-undang Nomor 13 Tahun 2003 Pasal 1 ayat (25) pemutusan hubungan kerja adalah pengakhiran hubungan kerja karena suatu hal tertentu yang mengakibatkan berakhirnya hak dan kewajiban antara pekerja atau buruh dan pengusaha. Menurut Imam Soepomo PHK merupakan "permulaan dari segala pengakhiran, permulaan dari berakhirnya dari mempunyai pekerjaan, permulaan dari berakhirnya kemampuan membiayai keperluan hidup sehari-hari baginya dan keluarganya, permulaan dari berakhirnya kemampuan menyekolahkan anak dan sebagainya" (Iman Soepomo, 1983:115-116).

Macam-macam PHK ada empat menurut UU No. 13 Tahun 2003 yaitu:

1. PHK Yang Dilakukan oleh Pengusaha. PHK ini dapat terjadi dalam hal:

1. Pekerja atau buruh melakukan kesalahan berat (Pasal 158 ayat (1) UU No. 13 Tahun 2003) yaitu kesalahan berat yang dilakukan pekerja.

Pekerja atau buruh telah melakukan:

- Melakukan penipuan, pencurian atau penggelapan barang atau uang milik perusahan;

- Memberikan keterangan palsu atau yang dipalsukan sehingga merugikan perusahaan;

- Mabuk, minum-minuman keras yang memabukan, memakai dan atau pengedaran narkotika, psikotropika dan zat adiktif lainya dilingkungan kerja;

- Melakukan perbuatan asusila atau perjudian dilingkungan kerja;

- Menyerang, menganiaya, mengancam atau mengintimidasi teman sekerja atau pengusaha di lingkungan kerja; 
- Membujuk teman sekerja atau pengusaha untuk melakukan perbuatan yang bertentangan dengan peraturan perundangundangan

- Dengan ceroboh atau dengan sengaja merusak barang milik perusahaan, ceroboh atau sengaja membiarkan teman sekerja atau pengusaha dalam keadaan bahaya;

- Membongkar dan membocorkan rahasia perusahaan yang seharusnya dirahasiakan kecuali untuk kepentingan Negara;

- Melakukan perbuatan lainnya dilingkungan perusahaan yang diancam pidana penjara 5 tahun atau lebih.

Tetapi kesalahan berat tersebut harus didukung bukti menurut UU No 13 Tahun 2003 Pasal 158 ayat (2) seperti:

- Pekerja atau buruh tertangkap tangan;

- Adanya pengakuan pekerja atau buruh yang bersangkutan

- Serta bukti lain berupa laporan kejadian yang dibuat oleh pihak berwenang di perusahaan yang bersangkutan dan didukung oleh sekurang-kurangnya dua orang saksi.

Apabila pekerja atau buruh tidak menerima PHK dengan alasan melakukan kategori kesalahan berat seperti tersebut diatas maka pekerja atau buruh yang bersangkutan dapatmengajukan gugatan kelembagaan penyelesaian perselisihan hubungan industrial. Gugatan tersebut dapat dilakukan dalam waktu satu tahun dan kalau lebih dari satu tahun sudah kadaluwarsa.

2. Pekerja atau buruh melanggar disiplin (Pasal 161 UU No. 13 Tahun 2003) Dalam suatu hal apabila pekerja atau buruh melakukan pelanggaran terhadap ketentuan yang diatur dalam perjanjian kerja, peraturan perusahaan atau perjanjian kerja bersama, pengusaha dapat melakukan PHK kepada pekerja atau buruh yang bersangkutan setelah diberikan peringatan pertama, kedua dan ketiga secara berturut-turut. Dalam hal surat peringatan diterbitkan secara berurutan maka surat peringatan pertama berlaku untuk jangka waktu 6 (enam) bulan. Surat peringatan yang sebagaimana dimaksud di atas masing-masing berlaku untuk jangka waktu 6 (enam) bulan. Kecuali ditetapkan dalam 
perjanjian kerja, peraturan perusahaan, atau perjanjian kerja bersama. Masingmasing Surat peringatan dapat diterbitkan secara berurutan atau tidak sesuai dengan ketentuan yang diatur dalam perjanjian kerja, peraturan perusahaan atau peraturan kerja bersama. Apabila pekerja atau buruh melakukan kembali pelanggaran ketentuan dalam perjanjian kerja, peraturan perusahaan atau dalam perjanjian kerja bersama masih dalam tenggang waktu 6 (enam) bulan maka pengusaha dapat menerbitkan Suratperingatan kedua yang juga mempunyai jangka waktu berlaku selama 6 (enam) bulan sejak diterbitkan peringatan kedua. Dalam suatu hal apabila pekerja atau buruh masih melakukan pelanggaran maka pengusaha dapat menerbitkan peringatan ketiga atau peringatan terakhir yang berlaku selamaenam bulan sejak diterbitkan Surat peringatan ketiga. Apabila dalam kurun waktu peringatan ketiga pekerja atau buruh kembali melakukan pelanggaran ketentuan dalam perjanjian kerja maka pengusaha dapat melakukan PHK. Dalam hal jangka waktu 6 (enam) bulan sejak diterbitkannya surat peringatan pertama sudah terlampaui maka apabila pekerja/buruh yang bersangkutan melakukan kembali pelanggaranketentuan perjanjian kerja, peraturan perusahaan atua perjanjiankerja bersama maka surat peringatan yang diterbitkan olehpengusaha adalah kembali sebagai peringatan pertamademikian juga berlaku bagi peringatan kedua dan ketiga.

Di dalam perjanjian kerja, peraturan perusahaan atauperjanjian kerja bersama dapat memuat pelanggaran tertentuyang dapat diberi peringatan pertama dan terakhir. Apabila pekerja atau buruh melakukan pelanggaran ketentuan dalamperjanjian kerja, peraturan perusahaan atau perjanjian kerjabersama dalam tenggang waktu masa berlakunya peringatanpertama dan terakhir, pengusaha dapat melakukan PHK.Tenggang waktu 6 (enam) bulan dimaksudkan sebagai upayamendidik pekerja atau buruh agar dapat memperbaikikesalahannya dan disisi lainnya, dan waktu 6 (enam) bulanmerupakan waktu yang cukup bagi pengusaha untukmelakukan penilaian terhadap kinerja pekerja atau buruh yangbersangkutan.

Pekerja atau buruh yang mengalami PHK dengan alasansebagaimana tersebut di atas, berhak memperoleh uangpesangon sebesar satu kali ketentuan pasal 156 ayat (2), uangpenghargaan masa kerja sebesar satu kali ketentuan 
pasal 156ayat (3) dan uang penggantian hak sesuai dengan ketentuanpasal 156 ayat (4) UU 13 Tahun 2003.

3. Terjadinya perubahan status penggabungan penutupan perusahaan atau pailit (Pasal 163 dan 165 UU No. 13 Tahun 2003)

Pengusaha dapat melakukan PHK terhadap pekerja/buruh dalam hal terjadi perubahan status, penggabungan, peleburan, atau perubahan kepemilikian perusahaan apabila pekerja atau buruh tidak bersedia melanjutkan hubungan kerja maka pekerja atau buruh yang bersangkutan berhak atas uang pesangon sebesar satu kali sesuai ketentuan Pasal 156 ayat (2), uang penghargaan masa kerja sebesar satu kali ketentuan Pasal 156 ayat (3) dan uang penggantian hak sesuai dengan ketentuan Pasal 156 ayat (4) UU 13 Tahun 2003. Sebaliknya apabila pengusaha menolak pekerja/ buruh untuk bekerja atas uang pesangon sebesar 2 (dua) kali ketentuan Pasal 156 ayat (2), uang penhargaan masa kerja 1 (satu) kali ketentuan dalam Pasal 156 ayat (3) dan uang penggantian hak sesuai ketentuan Pasal 156 ayat (4) Undang-undang Nomor 13 Tahun 2003.

4. Perusahaan tutup

Pengusaha dapat melakukan PHK terhadap pekerja atau buruh karena perusahaan tutup yang disebabkan perusahaan mengalami kerugian terusmenerus selama dua tahun atau keadaan memaksa (forsemajeur) dengan ketentuan pekerja atau buruh berhak uang atas pesangon sebesar 1 (satu) kali sesuai ketentuan Pasal 156 ayat (2), uang penghargaan masa kerja sebesar satu kali ketentuan Pasal 156 ayat (3) dan uang penggantian hak sesuai dengan ketentuan Pasal 156 ayat (4) UU 13 Tahun 2003. Kerugian perusahaan sebagaimana dimaksud di atas harus dibuktikan dengan laporan keuangan 2 (dua) tahun terakhir yang telah diaudit oleh akuntan publik.

5. Perusahaan melakukan efisiensi

Pengusaha dapat melakukan PHK terhadap pekerja atau buruh karena perusahaan tutup bukan karena mengalami kerugian selama dua tahun berturutturut atau bukan karena keadaan memaksa (forsemajeur) tetapi perusahaan melakukan efisiensi maka pekerja atau buruh berhak atas uang pesangon sebesar dua kali ketentuan Pasal 156 ayat (2), uang penghargaan masa kerja 
sebesar satu kali ketentuan Pasal 156 ayat (3) dan uang penggantian hak sesuai dengan ketentuan Pasal 156 ayat (4) UU 13 Tahun 2003.

6. Pekerja mangkir lima hari kerja berturut-turut (Pasal 168 UU No. 13 Tahun 2003)

Pekerja atau buruh yang mangkir selama lima hari kerja atau lebih berturutturut tanpa keterangan secara tertulis yang dilengkapi bukti yang sah dan telah di panggil dua kali secara patut dan tertulis dapat diputuskan hubungan kerjanya karena dikualifikasikan mengundurkan diri. Keterangan tertulis dengan bukti yang sah sebagaimana dimaksud di atas harus diserahkan paling lambat pada hari pertama pekerja/ buruh masuk bekerja. PHK sebagaimana dimaksud diatas pekerja/buruh yang bersangkutan menerima uang penggantian hak sesuai ketentuan Pasal 156 ayat (4) dan diberikan uang pisah yang besarnya dan pelaksanaanya diatur dalam perjanjian kerja, peraturan perusahaan atau perjanjian kerja bersama.

Apabila PHK yang dilakukan oleh pengusaha tidak memenuhi ketentuan sebagaimana tersebut di atas maka PHK tersebut batal demi hukum dan pengusaha wajib memperkerjakan pekerja atau buruh yang bersangkutan serta membayar seluruh upah dan hak yang seharusnya diterima.

2. PHK Atas Permintaan Pekerja atau Buruh adalah Pekerja atau buruh mengundurkan diri (Pasal 162 UU No. 13 Tahun 2003)

3. PHK yang Putus Demi Hukum

1. PHK karena pensiun (Pasal 167 UU No.13 Tahun 2003)

2. Pekerja karena meninggal dunia (Pasal 166 UU No.13 Tahun 2003)

4. PHK yang dilakukan oleh pengadilan, akibat adanya tindak pidana tetapi atas pengaduan pengusaha (Pasal 160 No. 13 Tahun 2003)

Syarat-syarat PHK

1. Setiap pemutusan hubungan kerja di perusahaan harus mendapatkan izin dari P4D untuk pemutusan kerja perorangan dan $\mathrm{P} 4 \mathrm{P}$ untuk pemutusan hubungan kerja massal (10 orang pekerja atau lebih pada satu perusahaan dalam satu bulan atau rentetan pemutusan hubungan kerja yang dapat menggambarkan suaru itikad pengusaha untuk mengadakan pemutusan hubungan kerja secara besar-besaran) 
2. Pengecualian dari ketentuan nomor 1 di atas, perusahaan dapat memutuskan hubungan kerja tanpa izin kepada $\mathrm{P} 4 \mathrm{D}$ atau $\mathrm{P} 4 \mathrm{P}$, apabila :

a. Pekerja dalam masa percobaan.

b. Pekerja mengajukan permintaan mengundurkan diri secara tertulis atas kemauan sendiri tanpa mengajukan syarat.

c. Pekerja telah mencapai usia pensiun yang ditetapkan dalam perjanjian kerja atau peraturan perusahaan (PP) atau kesepakatan kerja bersama (KKB).

d. Pekerja telah mencapai usia pensiun yang ditetapkan dalam perjanjian kerja, PP atau KKB.

e. Berakhirnya perjanjian kerja waktu tertentu.

f. Pekerja meninggal dunia.

Prosedur PHK:

1. Pengusaha harus mengusahakan agar jangan terjadi pemutusan hubungan kerja.

2. Setelah diadakan segala usaha dimana pemutusan hubungan kerja tidak dapat dihindarkan, maka pengusaha harus merundingkan maksudnya untuk mengadakan pemutusan hubungan kerja dengan organisasi pekerja yang bersangkutan yang ada di perusahaan atau dengan pekerja sendiri dalam hal tenaga kerja tersebut tidak menjadi anggota salah satu organisasi pekerja.

3. Bila perundingan tersebut tidak menghasilkan suatu kesepakatan, maka salah satu pihak atau para pihak mengajukan permintaaan untuk diperantai oleh pegawai perantara sesuai dengan tingkat kewenangannya.

4. Dalam hal pemerantaraan dimaksud tidak mencapai kesepakatan penyelesaian, pegawai perantara harus membuat anjuran secara tertulis yang memuat saran akhir kepada para pihak.

5. Pengusaha hanya dapat melakukan PHK setelah mendapat izin dari Panitia Penyelesaian Perselisihan Perburuhan.

6. $\mathrm{P} 4 \mathrm{D} / \mathrm{P} 4 \mathrm{P}$ wajib menyelesaikan permohonan izin pemutusan hubungan kerja dalam waktu yang sesingkat-singkatnya menurut tata cara yang berlaku. Dalam hal $\mathrm{P} 4 \mathrm{D} / \mathrm{P} 4 \mathrm{P}$ memberikan izin, maka dapat pula ditetapkan kewajiban pengusaha untuk memberikan uang pesangon, uang jasa, dan ganti kerugian lainnya.

Menurut Siswanto Sastrohadiwiryo dalam buku Manajemen Tenaga Kerja Indonesia (2008:307) berdasarkan sifatnya pemutusan hubungan kerja dapat dibedakan 
menjadi:

1. Pemutusan Hubungan Kerja secara Hormat

Pemutusan hubungan kerja antara perusahaan dengan tenaga kerja terjadi karena hal berikut:

- Keinginan tenaga kerja yang bersangkutan

- Telah mencapai batas waktu kontrak kerja

- Terjadi perekrutan tenaga kerja baru

- Tenaga kerja yang bersangkutan meninggal dunia

2. Pemutusan Hubungan Kerja Sementara

Pemutusan hubungan kerja sementara antara perusahaan dengan tenaga kerja terjadi manakala tenaga kerja yang bersangkutan dikenakan tahanan sementara oleh yang berwenang karena diduga melakukan sesuatu tindak pidana kejahatan.

3. Pemutusan Hubungan Kerja dengan Tidak Hormat

Pemutusan hubungan kerja dengan tidak hormat dikatakan pemutusan hubungan kerja tanpa kompromi. Pemutusan hubungan kerja dengan tidak hormat secara terpaksa harus dilakukan oleh manajemen, karena hal-hal berikut:

- Tenaga kerja yang bersangkutan melanggar kerja serta janji yang telah disepakati pada saat mengadakan ikatan kerja bersama.

- Bertindak dan berperilaku yang merugikan perusahaan baik dalam kuantum besar maupun kecil.

- Tenaga kerja yang bersangkutan dinyatakan melakukan tindak pidana.

- Kemangkiran yang terus dilakukan dan telah diperingatkan beberapa kali oleh manajemen.

\section{METODE PENELITIAN}

Jenis penelitian ini menggunakan deskriptif analitis, guna untuk mendeskripsikan dan menganalisa perselisihan yang terjadi di CV. Anugrah Jaya.Sumber data penelitian ini meliputi data primer dan data sekunder. Sumber data primer diperoleh melalui wawancara narasumer yaitu responden CV. Anugrah Jaya. Sedangkan sumber data sekunder ini yaitu data yang dikumpulkan untuk menunjang penelitian ini yang diperoleh dari data yang ada di Disnaker Kab. Bangkalan. Serta melalui studi kepustakaan dengan cara mempelajari 
literatur, artikel ilmiah, jurnal, data arsip, dan peraturan perundang-undangan yang relevan dengan masalah yanag dibahas.

\section{HASIL DAN PEMBAHASAN \\ Gambaran Umum CV. Anugrah Jaya}

$\mathrm{CV}$. Anugerah Jaya adalah perusahaan yang bergerak dibidang jasa otomotif yang berupa deler sepeda motor dan bengkel. CV. Anugerah Jaya terletak di Jl. Perdana Kaffa Bangkalan. Kebanyakan karyawan bekerja disana sebagai seles. Tugas utama karyawan seles adalah mencari klien. Sales pun juga dituntut untuk bisa mencapai target penjualan sepeda motor yang telah ditentukan oleh perusahaan. Apabila karyawan seles melebihi target yang sudah ditentukan, maka sales berhak mendapatkan bonus dari perusahaan.

\section{Bentuk Perselisihan Tenaga Kerja CV Anugerah Jaya}

Perselisihan tenaga kerja di CV Anugerah Jaya di Kab. Bangkalan merupakan kasus pengelapan uang yang dilakukan oleh salah satu pekerja yang bernama Ika Oktaviani. Permasalahannya, Ika Oktaviani merupakan Karyawan yang menjabat sebagai Koordinir seles. Dia telah menggelapkan uang bonus bagi seles yang telah melebihi target penjualan sepeda motor. Perbuatan Ika Okaviani dinilai telah melakukan tindak kriminal.

CV Anugerah Jaya akhirnya mengetahui tindakan yang dilakukan oleh Ika Oktaviani dikarenakan ada salah satu seles yang melaporkan bahwa upah atau gaji yang di dapat tidak sesuai dengan kontrak kerja. Dimana saat mereka telah melebihi pencapaian target yang dicapai, sales akanmendapatkan bonus. Atas pelaporan yang dilakukan oleh satu sales tersebut, akhirnya pihak CV. Anugrah Jaya menyelidiki lebih lanjut kasus ini. Dari beberapa bukti yang telah didapatkan, CV. Anugrah Jaya menuduh salah satu pekerjanya telah melakukan penggelapan uang. Karyawan tersebut bernama Ika Oktaviani yang menjabat sebagai koordinator sales. CV Anugerah Jaya tidak terima terhadap tindakan yang dilakukan oleh karyawan Ika Okavian karena tindakan tersebut sudah termasuk tindakan kriminal dan tidak dapat di toleransi. Akibat pengelapan uang yang dilakukan karyawan tersebut perusahaan melaporkan masalah tersebut kepada Dinas Industrial dan Tenaga Kerja Bangkalan.

\section{Bentuk penyelesaian perselisihan}


Pada kasus perselisihan tenaga kerja antara pekerja yaitu Ika Oktaviani dengan CV. Anugrah Jaya diselesaikan melalui Mediasi. Alasan CV. Anugrah Jaya memilih penyelesaian perselisihan tenaga kerja melalui mediasi karena perusahaan telah melakukan bipartid untuk menyelesaikan perselisihan yang terjadi antara pekerja dengan perusahaan. Namun jalur bipartid tersebut tidak menemukan titik temu. Karna pekerja tidak mau mengakui tindakan yang telah dilakukannya. Sehingga CV. Anugrah Jaya melakukan jalur tripatid yaitu mediasi dengan melaporkan kasus tersebut ke Dinas Perindustrian dan Tenaga Kerja Bangkalan.

Penyelesaian melalui mediasi dilakukan untuk penyelesaian perselisihan kepentingan, perselisihan pemutusan hubungan kerja, atau perselisihan antar serikat pekerja/ serikat buruh. Penyelesaian perselisihan melalui mediasi dilakukan oleh mediator yang terdaftar pada kantor instansi yang bertanggung jawab di bidang ketenagakerjaan Kabupaten Bangkalan.Peranan utama Mediator adalah melakukan mediasi hubungan industrial kepada para pihak yang berselisih. Mediator berkeinginan agar semua perselisihan hubungan industrial sebisa mungkin dapat selesai di tingkat mediasi, sehingga para pihak tidak harus melanjutkan perselisihan ke Pengadilan Hubungan Industrial.

Ciri utama mediasi merupakan perundingan yang esensinya sama dengan proses musyawarah atau konsensus. Sesuai dengan hakikat perundingan atau musyawarah atau konsensus, maka tidak boleh ada paksaan untuk menerima atau menolak sesuatu gagasan atau penyelesaian selama proses mediasi berlangsung. Segala sesuatunya harus memperoleh persetujuan dari para pihak. Urgensi dan motivasi dari mediasi agar para pihak yang berperkara menjadi damai dan tidak melanjutkan perkaranya dalam proses pengadilan. Apabila ada hal-hal yang mengganjal yang selama ini menjadi masalah, maka harus diselesaikan secara kekeluargaan dengan musyawarah mufakat. Mediator sangat menentukan efektivitas proses penyelesaian perselisihan, maka seorang mediator harus memenuhi kualifikasi tertentu.

\section{Tahapan Mediasi}

Proses penyelesaian perselisihan tenaga kerja melalui mediasi pada CV. Anugrah Jaya di kabupaten Bangkalan, dibagi dalam beberapa tahap. Tahapan mediasi (Syahrizal, 2011:36) adalah proses dari praktek yang harus dicermati secara seksama. Perlu adanya tahpan mediasi dikarenakan prosedur mediasi merupakan hal terpenting dalam 
penyelesaian suatu sengketa, pertikaian ataupun konflik. Adapun tahapan-tahapannya, yakni

a. Tahapan Pramediasi

Tahap pelaksanaan pada sidang pertama yang telah terjadwal atau telah ditentukan itu diisi dengan kehadiran kedua belah pihak, hakim mewajibkan para pihak untuk menempuh mediasi. Tahap pramediasi adalah tahap awal dimana mediator menyusun sejumlah langkah dan persiapan sebelum mediasi benar-benar dimulai. Pada tahap ini mediator melakukan beberapa langkah antara lain: membangun kepercayaan diri, menghubungi para pihak, menggali dan memberikan informasi awal mediasi, fokus pada masa depan, mengkoordinasikan pihak bertikai, mewaspadai perbedaan budaya, menentukan siapa yang hadir, menentukan tujuan pertemuan, kesepakatan waktu dan tempat, dan menciptakan rasa aman bagi kedua belak pihak untuk bertemu dan membicarakan perselisihan mereka.

Sebelum tahapan mediasi berlangsung, ada penjadwalan untuk pemanggilan kedua belah pihak yang bersangkutan untuk mengklarifikasi permasalahan yang terjadi. Pemanggilan tersebut tidak dijadikan dalam waktu yang bersamaan, melainkan ada jadwal tersendiri untuk pemanggilan. Yang pertama pemanggilan dari pihak pekerja, Ika Oktaviani dimintai keterangan akan permasalahaan yang terjadi. Yang kedua pemanggilan dari pihak CV. Anugrah Jaya. Penjadwalan pemanggilan ini bertujuan untuk memberikan info yang diperlukan oleh mediator agar mediator bisa memahami dan mengerti permasalahaannya.

b. Tahap pelaksanaan mediasi

Tahap pelaksanaan mediasi adalah tahap dimana pihak-pihak yang bertikai sudah berhadapan satu sama lain, dan memulai proses mediasi. Dalam tahapan ini, terdapat beberapa langkah penting antara lain: sambutan pendahuluan mediator, presentasi dan pemaparan kisah para pihak, mengurutkan dan menjernihkan permasalahan, berdiskusi dan bernegosiasi opsi-opsi, menemukan butir kesepakatan dan merumuskan keputusan, mencatat dan menuturkan kembali keputusan. Selain itu jika perlu, mediator dapat melakukan kaukus atau pertemuan antara mediator dengan salah satu pihak tanpa dihadiri oleh pihak lainnya.Dalam mediasi, musyawarah untuk mencapai mufakat adalah prioritas utama penyelesaian 
perselisihan. Bentuk musyawarah prasidang ini berupa kewajiban mediator untuk menganjurkan kepada para pihak yang berselisih untuk bermusyawarah dahulu dengan itikad baik sebelum dilaksanakan mediasi.

Namun dalam perselisihan antara Ika Oktaviani dengan CV. Anugrah tidak ditemukan titik temu karena sang pekerja tetap tidak mau mengakui perbuatannya dalam penggelapan uang perusahaan. Karena musyawarah prasidang gagal, barulah dilakukan musyawarah dengan perantaraan mediator dalam sebuah mediasi. Dengan adanya campur tangan orang ketiga yang netral membantu kedua belah pihak karna saat mediasi berlangsung Ika Oktaviani akhirnya mengakui perbuatannya yang telah menggelapkan uang perusahaan.

c. Tahap Akhir Implementasi Hasil Mediasi

Berdasarkan pengakuan Ika Oktaviani tersebut, pihak CV. Anugrah Jaya memutuskan kontrak kerja dengan Pemutusan Hubungan Kerja atau PHK karena tindakan kriminal yang merugikan perusahaan. Serta Ika Oktaviani dituntut untuk ganti rugi atas penggelapan uang perusahaan. Keputusan CV. Anugrah Jaya tersebut bisa diterima oleh Ika Oktaviani, sehingga perkara ini sudah dianggap selesai dijalur mediasi saja. Oleh karna itu, para pihak hanyalah menjalankan hasilhasil kesepakatan, yang telah mereka tuangkan bersama dalam suatu perjanjian tertulis. Para pihak menjalankan hasil kesepakatan berdasarkan komitmen yang telah mereka tunjukkan selama dalam proses mediasi.

Menurut Amirudin (2010:67) bahsawannya perundingan antara mediator dan para pihak tersebut dicantumkan dalam Risalah Penyelesaian Perselisihan Hubungan Industrial Secara Mediasi. Jika dalam sidang mediasi tercapai kesepakatan, maka dibuat Perjanjian Bersama yang ditandatangani oleh para pihak. Dalam hal mediasi tidak menemui kesepakatan maka mediator akan mengeluarkan anjuran tertulis yang nantinya akan dijawab oleh para pihak apakah menyetujui atau menolak anjuran tertulis. Apabila pihak menyetujui anjuran tertulis akan dibuatkan Perjanjian Bersama untuk kemudian didaftar di Pengadilan Hubungan Industrial. Dengan dibuatkannya Perjanjian Bersama ini maka proses mediasi dapat dikatakan berakhir dan menemui kesepakatan.

\section{Hasil Mediasi}


Mediator dalam menyelesaikan perselisihan PHK pada tahap mediasi hasil yang dicapai ada 2 (dua) kemungkinan yaitu:

1. Surat Perjanjian Bersama

Penyelesaian kasus PHK yang dapat di selesaikan di tingkat mediasi, maka selanjutnya mediator membantu membuat Perjanjian bersama secara tertulis selambat-lambatnya tiga hari kerja sejak anjuran disetujui para pihak (pengusaha dan pekerja/buruh) yang kemudian ditandatangani oleh para pihak yang sepakat dengan perjanjian bersama itu dan disaksikan oleh mediator. Perjanjian Bersama bisa di peroleh dari awal sudah tercapai kesepakatan dan bisa setelah mediator memberikan anjuran.

Kesepakatan tersebut di atas harus ditandatangani oleh para pihak dan di saksikan oleh mediator Dinas Perindustrian dan Tenaga Kerja Bangkalan, yang menengahi proses penyelesaian PHK di luar Pengadilan tersebut. Sebelum menandatangani perjanjian kerja tersebut para pihak (pengusaha dan pekerja/ buruh) diberi kesempatan untuk membacanya dan memahami isinya. Perjanjian Bersama ini apabila disetujui mempunyai kekuatan mengikat bagi para pihak (pengusaha dan pekerja/ buruh) yang membuatnya, jika salah satu pihak mengingkari dapat diajukan ke Pengadilan Hubungan Industrial atau Pengadilan Negeri setempat dimana pihak-pihak membuat perjanjian.

2. Surat Anjuran

Pelaksanaan mediasi kadang berhasil atau memperoleh kesepakatan dan kadang tidak berhasil memperoleh kesepakatan. Pelaksanaan mediasi tidak selamanya menemukan jalan yang terbaik untuk pihak-pihak yang saling berselisih tetapi juga ada kasus yang tidak memperoleh titik temu atau menemukan jalan buntu di tingkat mediasi.Apabila ada pihak yang menolak anjuran tertulis atau tidak memberi tanggapan, maka mediator berkewajiban membuat risalah penyelesaian perselisihan yang digunakan sebagai lampiran surat gugatan ke Pengadilan Hubungan Industrial. Jika sampai pada proses ini maka mediasi sudah berakhir dan dapat dikatakan gagal dimediasi.

Dari hasil mediasi, perselisihan antara Ika Oktaviani dengan CV. Anugrah Jaya berujung dengan Surat Perjanjian Bersama karna penyelesaian kasus PHK dapat di selesaikan di tingkat mediasi, maka selanjutnya mediator membantu membuat Perjanjian 
bersama secara tertulis selambat-lambatnya tiga hari kerja sejak anjuran disetujui oleh pihak Ika Oktaviani dan pihak CV. Anugrah Jaya yang kemudian ditandatangani oleh para pihak yang sepakat dengan perjanjian bersama itu dan disaksikan oleh mediator.

\section{Efektifitas Mediasi}

Menurut Made (2012:192) Efektifitas mediasi dalam menyelesaikan perselisihan hubungan industrial tidak terlepas dari faktor pendorong dan penghambatnya. Faktor pendorong efektifitas mediasi dalam penyelesaian perselisihan hubungan industrial adalah adanya itikad baik dari para pihak. Selain mediator membantu para pihak agar keluar dari persengketaannya, para pihak juga harus mempunyai itikad baik dengan kesungguhan hati mengupayakan perdamaian dengan tidak bermaksud untuk memperoleh keuntungan yang lebih besar untuk menyelesaikan perselisihan mereka dengan perdamaian, para pihak mau menerima saran atau anjuran dari mediator karena saran atau anjuran itu bertujuan untuk mendamaikan para pihak sehingga mencapai kata sepakat.

Hadirnya para pihak dalam sidang mediasi merupakan hal yang harus diupayakan meskipun para pihak menggunakan jasa kuasa hukum. Pasal 14 ayat (2) Keputusan Menteri Tenaga Kerja dan Transmigrasi Nomor 92 Tahun 2004 menyatakan bahwa para pihak yang berselisih harus selalu hadir meskipun para pihak yang berselisih mewakilkan penyelesaiannya kepada kuasa hukum. Pada prakeknya pihak pekerja seringkali diwakilkan oleh serikat pekerja dimana pekerja tersebut menjadi anggota dari serikat pekerja tersebut. Umumnya menurut penuturan salah satu mediator, pihak pekerja yang telah diwakilkan tidak perlu hadir karena telah memberikan kuasa kepada serikat pekerja, pihak pekerja akan hadir jika diminta oleh mediator. Mediator meminta pekerja hadir agar mediator dapat mengetahui siapa saja pekerja yang diwakilkan oleh kuasanya. Dan juga pada saat mediator membutuhkan keterangan tambahan dari pihak pekerja.

Mediator juga menentukan efektivitas proses penyelesaian perselisihan, maka mediator harus secara layak memenuhi kualifikasi tertentu serta berpengalaman dalam komunikasi dan negosiasi agar mampu mengarahkan para pihak yang berselisih (bersengketa). Mediator yang bersifat netral dan tidak memihak kepada salah satu pihak dan keberhasilan mediasi juga tidak terlepas dari pengetahuan yang luas tentang hukum ketenagakerjaan yang dimiliki oleh mediator serta keterampilan dalam mediasi. Dalam praktik, mediator sangat membutuhkan kemampuan personal yang memungkinkannya berhubungan secara menyenangkan dengan masing-masing pihak. Kemampuan pribadi 
yang terpenting adalah sifat tidak menghakimi, yaitu dalam kaitannya dengan cara berfikir masing-masing pihak serta kesiapannya untuk memahami dengan empati pandangan para pihak. Mediator perlu memahami dan memberikan reaksi postif (meskipun tidak berarti setuju) atas persepsi masing-masing pihak dengan tujuan membangun hubungan baik dan kepercayaan. Jika para pihak sudah percaya kepada mediator dan proses mediasi, mediator akan lebih mampu membawa mereka ke arah konsensus. Faktor-faktor tersebutlah yang mendorong efektivitas mediasi sebagai penyelesaian perselisihan.

\section{KESIMPULAN DAN SARAN}

\section{Kesimpulan}

Mediasi yang dilakukan dalam penyelesaikan perselisihan pemutusan hubungan kerja pada CV. Anugrah Jaya di Dinas Perindustrian dan Tenaga Kerja Bangkalan berjalan efektif. Saat berlangsungnya mediasi, mediator berperan aktif untuk menyelaraskan tujuan bersama dengan menghasilkan mufakat diantara kedua belah pihak. Dengan terjadinya perjanjian bersama, perselisihan hubungan industrial telah selesai, sehingga mediator telah menjalankan fungsinya untuk membantu para pihak menyelesaikan perselisihan.

Dengan adanya mediasi, perselisihan antara Ika Oktaviani dengan CV. Anugrah Jaya bisa menemukan titik temu yang bisa disepakati oleh kedua belah pihak. Pengakuan dari Ika Oktaviani yang telah menggelapkan uang perusahaan dianggap telah merugikan perusahaan. Sehingga keputusan akhir dari mediasi ini adalah pemutusan hubungan kerja atau yang sering disebut dengan PHK, serta ganti rugi bagi Ika Oktaviani. Peran mediator disini juga sangat penting bagi keselangsungan mediasi, karna sebagai penengah tidak mudah untuk membantu menemukan jalan keluar untuk mufakat.

Efektifitas mediasi dalam menyelesaikan perselisihan hubungan industrial tidak terlepas dari faktor pendorong dan penghambatnya. Faktor pendorong efektifitas mediasi dalam penyelesaian perselisihan hubungan industrial adalah adanya itikad baik dari para pihak. Selain mediator membantu para pihak agar keluar dari persengketaannya, para pihak juga harus mempunyai itikad baik dengan kesungguhan hati mengupayakan perdamaian dengan tidak bermaksud untuk memperoleh keuntungan yang lebih besar untuk menyelesaikan perselisihan mereka dengan perdamaian, para pihak mau menerima saran atau anjuran dari mediator karena saran atau anjuran itu bertujuan untuk mendamaikan para pihak sehingga mencapai kata sepakat. 


\section{Saran}

1. Pengusaha

Apabila ada perselisihan antara pekerja dengan perusahaan, sebaiknya perusahaan melakukan bipartid terlebih dahulu. Jika tidak menemukan jalan keluar barulah menggunakan jalur tripatid.

2. Pekerja

Alangkah baiknya, jika pekerja selalu jujur terhadap segala tindakan yang telah dilakukannya, sehingga pekerja bisa amanah dalam mengemban tugasnya

3. Dinas Perindustrian dan Tenaga Kerja Bangkalan

Diharapkan agar pihak Dinas Perindustrian dan Tenaga Kerja Bangkalan yang berperan sebagai mediator dalam mediasi lebih aktif lagi ketika mediasi berlangsung.

\section{DAFTAR PUSTAKA}

Abbas, Syahrizal. 2011. Mediasi dalam Hukum Syariah, Hukum Adat, dan Hukum Nasional. Jakarta: Kencana

Amiruddin dan H. Zainal Asikin, 2010, Pengantar Metode Penelitian Hukum, Jakarta: PT Raja Grafindo Persada

Asri Wijayanti, 2010. Hukum Ketenagakerjaan Pasca Reformasi, Jakarta: Sinar Grafika, hlm. 158.

B. Siswanto, Sastrohadiwiryo. 2008. Manajemen Tenaga Kerja Indonesia. Jakarta: PT Bumi Aksara

Budiono, Abdul, R. 2011. Hukum Perburuhan. Jakarta: Indeks.

I Made Sukadana, 2012, Mediasi Peradilan Mediasi Dalam Sistem Peradilan PerdataIndonesia Dalam Rangka Mewujudkan Proses Peradilan Yang Sederhana, Cepat dan Biaya Ringan, Jakarta: Prestasi Pustaka, h. 192.

Imam Soepomo. 1976. Hukum Perburuhan Bidang Hubungan Kerja. Jakarta: Djambatan Kurniawan, Agung. 2005. Transformasi Pelayanan Publik. Yogyakarta: Pembaruan.

Siagian, Sondang P, 2008. Manejemen Sumber Daya Manusia. Cetakan Enam Belas. Jakarta: Bumi Aksara.

Saifullah, Muhammad. 2009. Mediasi dalam Tinjauan Hukum Islam dan Hukum Positif di Indonesia. Semarang: Walisongo

Takdir, Rahmadi. 2011. Mediasi Penyelesaian Sengketa Melalui Pendekatan Mufakat. Jakarta: PT. Rajagrafindo Persada

\section{Sumber lain}

A Martana, Nyoman. Artikel Efektivitas Pelaksanaan Mediasi Sebagai Alternatif Penyelesaian Sengketa Perselisihan Hubungan Industrial

Faqhan, Ali. 2016. Skripsi Mediasi Dalam Penyelesaian Perselisihan Hubungan Industrial di Dinas Sosial, Tenaga Kerja dan Transmigrasi Kota Yogyakarta 
Hasan, Muhamad. 2013. Skripsi Efektivitas Mediasi Sebagai Upaya Penyelesaian Perselisihan Hubungan Industrial (Studi Proses Mediasi Pada Balai Pelayanan Penyelesaian Perselisihan Tenaga Kerja (BP3TK) Jawa Tengah)

Handayani, Pristika. 2017. Jurnal Penyelesaian Sengketa Melalui Mediasi Terhadap Pemutusan Hubungan Kerja di Kota Batam. Vol IV, No. 1

Kurnia, Lusy. Artikel Efektivitas Mediasi Sebagai Upaya Penyelesaian Perselisihan Pemutusan Hubungan Kerja (Studi di Dinas Ketenagakerjaan dan Transmigrasi kota Malang)

Undang-Undang No.2 Tahun 2004 tentang Perselisihan Hubungan Industrial.

Undang-Undang Nomor 13 Tahun 2003 tentang Ketenagakerjaan. http://rennomahardhika.blogspot.com/2012/04/prosedur-pemutusan-hubungankerja-phk.html?m=1 